\title{
PENGARUH PENUNDAAN PENANGANAN SPUTUM TERHADAP HASIL PEMBACAAN SEDIAAN SECARA MIKROSKOPIS PADA PENDERITA TB DI UPT. LABORATORIUM KESEHATAN DAERAH PROVINSI SUMATERA UTARA
}

\author{
Nelma ${ }^{1}$, Armida Lumbantoruan ${ }^{2}$ \\ Jurusan Analis Kesehatan Politeknik Kesehatan Medan
}

\begin{abstract}
The background of the study is whether there are differences in the results of microscopic smear reading and the quality of direct sputum preparations, check with sputum 24 hours at room temperature. The purpose of the study was to determine the effect of delaying the handling of sputum on the results of microscopic readings of preparations in tuberculosis patients. Type of descriptive observation research. Research time June 2019. Research location at the Regional Health Laboratory of North Sumatra Province. The results showed that from 16 sputum samples that were immediately examined, the scanty results were 2 samples, $1+$ there were 2 samples, $2+$ there were 2 samples, $3+$ there were 10 samples, whereas in the 24 hour sample at room temperature, there were 2 negative results, $1+$ there are $4,2+$ there are 3 , and $3+$ there are 7 samples of BTA. Of the 16 sputum, they were immediately examined by delaying 24 hours at room temperature, 7 sputum were obtained, the results of which were reduced. There is no positive number added, the same number of positive results is 9 sputum. This suggests that a 24-hour delay in sputum examination at room temperature can result in false positives. There are differences in the results between sputum directly checked by being delayed 24 hours at room temperature $25^{\circ} \mathrm{C}$. It is recommended that an AFB sputum be examined immediately to avoid the results of false negative smear microscopic examination.
\end{abstract}

Keywords : sputum handling, BTA, bacteria

\section{PENDAHULUAN}

\subsection{Latar Belakang}

Tuberkulosis (TB) adalah suatu penyakit infeksi yang menular, yang disebabkan oleh kuman Mycobacterium tuberculosis. Penularan langsung terjadi melalui aerosol yang mengandung kuman TB. Penyakit ini dapat menyerang semua kelompok umur dan semua organ tubuh manusia, terutama paru. Gejala umum TB paru pada orang dewasa adalah batuk yang terus menerus dan berdahak selama 2-3 minggu atau lebih. Bila tidak diobati maka setelah lima tahun sebagian besar (50\%) pasien akan meninggal (Kemenkes RI, 2012).

Tuberkulosis (TB) sampai dengan saat ini masih merupakan salah satu masalah kesehatan masyarakat di dunia walaupun upaya penanggulangan TB telah dilaksanakan dibanyak negara sejak tahun 1995.

Situasi kasus TB di Indonesia, menurut laporan WHO tahun 2015, jumlah kasus TB di Indonesia diperkirakan ada 1 juta kasus TB baru pertahun (399 per 100.000 penduduk) dengan 100.000 kematian pertahun (41 per 100.000 penduduk). Diperkirakan 63.000 kasus TB dengan HIV positif (25 per 100.000 penduduk). Angka Notifikasi Kasus (Case Notification Rate/ CNR) dari semua kasus, dilaporkan sebanyak 129 per 100.000 penduduk. Jumlah seluruh kasus 324.539 kasus, diantaranya 314.965 adalah kasus baru. Secara nasional perkiraan prevalensi HIV diantara pasien TB diperkirakan sebesar 6,2\%. Jumlah kasus TB-RO diperkirakan sebanyak 6700 kasus yang berasal dari 1,95\% kasus TB-RO dari kasus baru TB dan ada 12\% kasus TB-RO dari TB dengan pengobatan ulang (Kemenkes RI, 2017).

Indonesia menempati posisi kedua dengan beban TB tertinggi di dunia. TB di Indonesia juga merupakan penyebab kematian nomor dua di dunia setelah penyakit kardiovaskular. Angka TB di Indonesia berdasarkan mikroskopik sebanyak 759 per 100.000 penduduk untuk usia 15 tahun ke atas dengan jumlah laki- laki lebih tinggi daripada perempuan, dan jumlah diperkotaan lebih tinggi daripada pedesaan. (WHO, 2016).

Provinsi Sumatera Utara yang terdiri dari 33 kabupaten/kota memiliki jumlah penderita pasien TB tahun 2016 tercatat 22.866 kasus. Jumlah penderita TB. klinis di Sumatera Utara pada tahun 2016 sebanyak 106.453 orang. Jumlah penderita yang positif setelah dilakukan pemeriksaan dan diobati sebanyak 14.844 orang serta angka keberhasilan pengobatan (sembuh) sebanyak 11.611 orang atau sekitar 78,2\% (Dinkes Prov. Sumatera Utara, 2016).

Jumlah penderita klinis TB yang positif di Kota Medan tahun 2016 setelah dilakukan pemeriksaan ada sebanyak 14.602 orang, dan yang diobati sebanyak 7.163 orang serta angka keberhasilan pengobatan (sembuh) 
sebanyak 5.021 orang $(70,1 \%)$. Proporsi penderita penyakit TB di Kota Medan dari seluruh penderita di Provinsi Sumatera Utara adalah sebesar 17,2\% merupakan wilayah dengan penderita tertinggi kedua setelah Kota Sibolga $21,1 \%$ dan Kota Pematang Siantar 16,3\%. Namun tingkat kesembuhan hanya 70,1\% sedangkan target nasional sebesar 80\% (Dinkes Prov. Sumatera Utara, 2016).

Salah satu pelayanan yang diberikan di dalam program penanggulangan TB kepada penderita TB adalah pemeriksaan laboratorium, pemeriksaan sediaan mikroskopis BTA dari spesimen dahak merupakan komponen kunci untuk menegakkan diagnosis serta evaluasi dan tindak lanjut pengobatan. Pemeriksaan dahak untuk penegakan diagnosis dilakukan dengan mengumpulkan 2 contoh uji dahak, terdiri dari dahak sewaktu dan dahak pagi (Kemenkes RI, 2017).

Diagnosa TB melalui pemeriksaan biakan dahak merupakan metode baku emas (gold standard). Namun pemeriksaan biakan memerlukan waktu lebih lama (paling cepat sekitar 6 minggu). Harus dilakukan dengan peralatan khusus. Pemeriksaan dahak mikroskopis efisien, mudah, murah, bersifat spesifik, sensitif dan dapat dilaksanakan di semua unit laboratorium fasilitas pelayanan kesehatan yang memiliki mikroskop dan tenaga mikroskopis TB terlatih (Kemenkes RI, 2017).

Pemeriksaan dahak secara mikroskopis langsung yang bermutu merupakan komponen penting dalam penegakan diagnosis maupun follow up. Hasil pemeriksaan dahak yang bermutu merupakan hal yang penting untuk menetapkan klasifikasi penderita, keputusan untuk memulai pengobatan dan menyatakan kesembuhan penderita. Mutu hasil pemeriksaan laboratorium merupakan inti keberhasilan penanggulangan tuberculosis. Setiap laboratorium yang melakukan pemeriksaan TB harus melakukan pemeriksaan BTA secara mikroskopis.

Berdasarkan hasil penelitian, Teguh Budiharjo (2016) kualitas sputum untuk pemeriksaan laboratorium adalah penting. Sputum yang baik mengandung beberapa partikel atau sedikit kental dan berlendir, kadang bernanah dan berwarna hijau kekuningan. Guna menjamin spesimen bermutu baik, harus segera dikirim ke laboratorium setelah pengambilan dan dilakukan pemeriksaan. Jika sputum disimpan pada suhu kamar selama satu hari (24 jam) dapat mengakibatkan sputum menjadi encer dan kualitas sediaan menjadi tidak baik, dan baunya lebih tajam. Ada perbedaan hasil dan kualitas sediaan antara sputum langsung diperiksa dengan sputum ditunda pemeriksaannya setelah 24 jam pada suhu kamar.

Kegiatan petugas laboratorium tidak hanya pemeriksaan suspek TB paru saja, kadang masih dibebani dengan kegiatan rutin laboratorium lainnya, sehingga kadang sputum yang diambil dari suspek TB disimpan dulu pada suhu kamar sehari baru diperiksa.

Pemeriksaan laboratorium yang banyak dengan jumlah petugas laboratorium yang sedikit, sehingga petugas menunda pemeriksaan BTA. Pemeriksaan sputum BTA yang ditunda dan dibiarkan pada suhu kamar, kualitas sputum akan berubah, lebih encer dan kadang sulit di lakukan koil koil kecil pada kaca sediaan.
Kualitas sputum akan ikut menentukan hasil pemeriksaan mikroskopis BTA. Sediaan dahak yang baik adalah sediaan yang memenuhi 6 syarat kualitas sediaan yang baik yaitu kualitas contoh uji, ukuran, ketebalan, kerataan, pewarnaan dan kebersihan (Kemenkes RI, 2017).

Berdasarkan fenomena tersebut yang melatar belakangi ketertarikan untuk meneliti tentang efek penundaan penanganan sputum TB Paru selama 24 jam di suhu kamar terhadap hasil pemeriksaan mikroskopis BTA secara langsung.

\subsection{Perumusan Masalah}

Dalam penelitian ini didapatkan rumusan masalah yaitu apakah terdapat pengaruh penundaan penanganan sputum terhadap hasil pembacaan sediaan secara mikroskopis pada penderita tuberkulosis di UPT. Laboratorium Kesehatan Daerah Provinsi Sumatera Utara.

\subsection{Tujuan Penelitian \\ 1.3.1 Tujuan Umum}

1. Untuk mengetahui pengaruh penundaan penanganan sputum terhadap hasil pembacaan sediaan secara mikroskopis pada penderita tuberkulosis di UPT. Laboratorium Kesehatan Daerah Provinsi Sumatera Utara.

\subsubsection{Tujuan Khusus}

1. Untuk menentukan pengaruh penundaan penanganan sputum terhadap hasil pembacaan sediaan secara mikroskopis pada penderita tuberkulosis di UPT. Laboratorium Kesehatan Daerah Provinsi Sumatera Utara.

\subsection{Manfaat Penelitian}

1. Bagi Profesi Kesehatan

a. Meningkatkan pengetahuan tenaga kesehatan mengenai pengaruh penundaan penanganan sputum terhadap hasil pembacaan sediaan secara mikroskopis pada penderita tuberkulosis.

b. Meningkatkan peran tenaga kesehatan sebagai pelaksana dalam memberikan edukasi kesehatan masyarakat tentang pemeriksaan penyakit tuberkulosis.

\section{METODE PENELITIAN}

\subsection{Jenis Penelitian}

Jenis penelitian ini menggunakan Analisa Laboratorium yang bersifat Deskriftif observasi dengan Uji Pewarnaan BTA Metode Ziehl Neelsen untuk mengidentifikasi Basil Tahan Asam (BTA) pada sampel Sputum yang diperiksa langsung dan yang dibiarkan 24 jam pada suhu kamar dari sampel yang ada di UPT. Laboratorium Kesehatan Daerah Provinsi Sumatera Utara. Rancangan percobaan yang digunakan adalah rancangan cross sectional (RSC) dengan 16 (enam belas) sampel dan 2 (dua) kali pengulangan. 


\subsection{Lokasi dan Waktu Penelitian \\ 3.2.1 Lokasi Penelitian}

Penelitian ini dilaksanakan di UPT. Laboratorium

Kesehatan Daerah Provinsi Sumatera Utara dan pengambilan sampel dilakukan di UPT. Laboratorium Kesehatan Daerah Provinsi Sumatera Utara.

\subsubsection{Waktu Penelitian}

Waktu penelitian dilakukan pada bulan Juni 2019.

\subsection{Populasi dan Sampel Penelitian}

\subsubsection{Populasi}

Populasi penelitian ini adalah seluruh sputum BTA positif yang diperiksa dalam 1 (satu) bulan di UPT. Laboratorium Kesehatan Daerah Provinsi Sumatera Utara.

\subsubsection{Sampel}

Dalam penelitian ini jumlah sputum BTA positif adalah 16. Sputum dalam penelitian ini adalah sputum segar yang diperiksa langsung dan sputum yang dibiarkan 24 jam pada suhu kamar pada bulan Juni 2019 di UPT. Laboratorium Kesehatan Daerah Provinsi Sumatera Utara.

\subsection{Jenis Data} data primer

Jenis data yang digunakan untuk penelitian adalah

\subsubsection{Cara Pengumpulan Data}

1. Pengumpulan data dilakukan dengan cara pemeriksaan sampel sputum segar yang diperiksa langsung dan sputum yang dibiarkan 24 jam pada suhu kamar yang ada di UPT. Laboratorium Kesehatan Daerah Provinsi Sumatera Utara.

2. Hasil data yang diperoleh dengan pemeriksaan sputum yaitu ada tidaknya basil tahan asam (BTA). Setiap sampel yang ada langsung diperiksa dengan dilakukan pembacaan hasil dan uji kualitas sediaan dahak dengan 6 kriteria (kualitas contoh uji, ukuran, ketebalan, kerataan, pewarnaan, kebersihan). Untuk sampel sputum yan dibiarkan 24 jam pada suhu kamar juga dilakukan pembacaan hasil dan uji kualitas sediaan dahak.

\subsection{Bahan dan Alat}

\subsubsection{Bahan}

1. Carbol Fuchsin $1 \%$

2. HCl- Alkohol 3\%

3. Methylen Blue $0,1 \%$

4. Spiritus

\subsubsection{Alat}

1. Pot dahak bersih dan kering, diameter mulut pot 4-6 $\mathrm{cm}$, transparan, berwarna bening, bertutup ulir, tidak bocor.

2. Kaca sediaan frosted

3. Label, pensil, spidol.

4. Rak pewarnaan

5. Pinset/ penjepit kayu

6. Air mengalir/ botol semprot

7. Sulut api
8. Rak pengering
9. Pengatur waktu/ timer
10. Corong
11. Kertas sarng
12. Kain basah

\subsection{Prosedur Penelitian}

\subsubsection{Cara Pengambilan Sampel}

Sampel diambil dari pasien yang datang berkunjung ke UPT. Laboratorium Kesehatan Daerah Provinsi Sumatera Utara. Yang perlu dipersiapkan adalah pot sputum yang akan digunakan sebagai tempat sampel. Selanjutnya sampel diberi kode pada setiap wadah untuk membedakan sampel yang diperiksa. Sampel diperiksa di UPT. Laboratorium Kesehatan Daerah Provinsi Sumatera Utatra.

\subsubsection{Persiapan Alat dan Bahan}

Sebelum melakukan pemeriksaan sputum, hal yang perlu dipersiapkan di UPT.Laboratorium Kesehatan Daeran Provinsi Sumatera Utara adalah:

1. Pastikan semua alat yang digunakan pada penelitian dalam kondisi layak pakai dan bersih.

2. Reagensia Ziehl Neelsen masih layak dipergunakan.

\subsubsection{Metode Pemeriksaan}

Metode yang dilaksanakan adalah metode Ziehl Neelsen dan hasil dibaca dengan Skala IUATLD (International Union Against Tuberculosis and Lung Disease).

\subsubsection{Langkah - langkah Pemeriksaan Mikroskopis BTA}

1. Sampel Sputum Segar

Cara pembuatan sediaan dahak

Ambil contoh uji dahak segar pada bagian yang purulen dengan lidi yang telah dipipihkan ujungnya dengan tang. Sebarkan di atas kaca sediaan dengan bentuk oval ukuran $2 \times 3 \mathrm{~cm}$, kemudian ratakan dengan tusuk gigi membentuk spiral kecil-kecil. Jangan membuat gerakan spiral bila sediaan dahak sudah kering karena akan menyebabkan aerosol. Keringkan pada suhu kamar. Masukkan lidi dan tusuk gigi bekas ke dalam wadah yang dilapisi plastik (dibagian dalam) berisi desinfektan, Fiksasi dilakukan dengan memegang kaca sediaan dengan pinset, pastikan kaca sediaan menghadap ke atas. Lewatkan sediaan di atas api bunsen yang berwarna biru 2-3 kali selama 1-2 detik. Lakukan pewarnaan Metode Ziehl Neelsen.

2. Sampel Sputum 24 jam

Cara pembuatan sediaan dahak

Ambil contoh uji dahak 24 jam yang dibiarkan di suhu ruangan $25^{\circ} \mathrm{C}$ dengan lidi yang telah dipipihkan ujungnya dengan tang. Sebarkan di atas kaca sediaan dengan bentuk oval ukuran $2 \times 3 \mathrm{~cm}$, kemudian ratakan dengan tusuk gigi membentuk spiral kecil-kecil. Jangan membuat gerakan spiral bila sediaan dahak sudah kering karena akan menyebabkan aerosol. Keringkan pada suhu kamar. 
Masukkan lidi dan tusuk gigi bekas ke dalam wadah yang dilapisi plastik (dibagian dalam) berisi desinfektan, Fiksasi dilakukan dengan memegang kaca sediaan dengan pinset, pastikan kaca sediaan menghadap ke atas. Lewatkan sediaan di atas api bunsen yang berwarna biru 2-3 kali selama 1-2 detik. Lakukan pewarnaan Metode Ziehl Neelsen.

\subsubsection{Pewarnaan Metode Ziehl Neelsen}

Letakkan sediaan di atas rak dengan jarak 1 jari. Sediaan ditetesi larutan Carbol Fuchsin 1\% melalui corong yang dilapisi kertas saring, dimulai dari ujung kaca sediaan hingga menutupi seluruh permukaan kaca sediaan.

Panaskan sediaan dengan sulut api yang dicelupkan ke dalam spiritus sampai keluar uap (jangan sampai mendidih), kemudian dinginkan selama 10 menit. Matikan sulut api dengan menggunakan kain basah.

Bilas sediaan secara perlahan dengan air mengalir, jangan menyiramkan atau menyemprotkan air tepat pada apusan. Buang sisa air pada sediaan.

Tuangkan asam alcohol 3\% pada sediaan biarkan selama 3 menit lalu bilas dengan air sampai bersih, tidak tampak sisa zat warna merah. Bila masih tampak warna merah lakukan decolorisasi ulang 1 kali. Bilas dengan air mengalir. Buang sisa air.

Tuangkan methylene blue $0.1 \%$ hingga menutupi seluruh sediaan dan biarkan selama 1 menit. Bilas dengan air mengalir. Keringkan sediaan pada rak pengering.

\subsubsection{Pembacaan Sediaan Dahak}

Pembacaan sediaan dahak menggunakan mikroskop dengan lensa objektif

10x untuk menentukan focus, kemudian pada lensa objektif 100x.

Dilakukan pembacaan disepanjang garis horisontal terpanjang dari ujung kiri keujung kanan atau sebaliknya. Dengan demikian akan dibaca minimal 100 lapang pandang.

\subsubsection{Pelaporan Skala IUATLD}

Pelaporan hasil pemeriksaan mikroskopis dengan mengacu kepada skala International Union Against Tuberculosis and Lung Disease (IUATLD) .

Negatif : tidak ditemukan BTA dalam 100 lapang pandang.

Scanty : ditemukan 1- 9 BTA dalam 100 lapang pandang, (tuliskan jumlah BTA yang ditemukan).

1+ $\quad$ : ditemukan 10 - 99 BTA dalam 100 lapang pandang,

2+ $\quad$ : ditemukan 1-10 BTA setiap 1 lapang pandang, (periksa minimal 50 lapang pandang).

$3+\quad$ : ditemukan $\geq 10$ dalam 1 lapang pandang, (periksa minimal 20 lapang pandang)

\subsubsection{Kualitas Sediaan Dahak}

1. Kualitas contoh uji

Spesimen dahak berkualitas baik apabila ditemukan:

Lekosit PMN $\geq 25$ per LP pada perbesaran $10 \times 10$
Makrofag pada perbesaran 10 x 100

2. Ukuran sediaan dahak

Sediaan dahak yang baik berbentuk oval berukuran $2 \times 3 \mathrm{~cm}$.

3. Ketebalan

Penilaian ketebalan dapat dilakukan sebelum pewarnaan dan pada saat pemeriksaan mikroskopis. Penilaian ketebalan sebelum pewarnaan dilakukan dengan meletakkan sediaan sekitar $4 \mathrm{~cm}$ di atas kertas. Penilaian ketebalan dapat juga dilakukan setelah sediaan dahak diwarnai. Pada sediaan yang baik sel leukosit tidak tampak bertumpuk (one layer cells).

4. Kerataan

Penilaian kerataan dilakukan secara makroskopis dan mikroskopis dengan tidak tampak adanya daerah yang kososng. Sediaan yang baik pada setiap lapang pandang akan terlihat apusan dahak yang tersebar rata secara mikroskopis. Sediaan yang baik adalah sediaan yang rata dan tidak terlihat daerah kosong. Sediaan terlalu tebal, dan ada bagian yang terkelupas kemungkinan karena difiksasi sebelum kering atau pencucian dilakukan langsung di atas apusan. Sediaan tidak rata. Tidak dilakukan perataan dengan membuat spiral-spiral kecil.

5. Pewarnaan

Pada sediaan yang baik tampak jelas kontras antara BTA dan warna latar, bersih dan tidak tampak sisa zat warna.

6. Kebersihan

Penilaian kebersihan dilakukan secara makroskopis dan mikroskopis.

Sediaan yang baik terlihat bersih, tidak tampak sisa zat warna, endapan kristal. Sediaan yang kurang bersih akan mengganggu pembacaan secara mikroskopis.

Penilaian kualitas sediaan dahak yang baik dilakukan dengan menggunakan diagram sarang laba-laba

\section{HASIL DAN PEMBAHASAN}

\subsection{Hasil}

Dari hasil penelitian yang telah dilakukan terhadap 16 sampel sputum yang diperiksa langsung dan yang dibiarkan 24 jam pada suhu kamar dari sampel yang ada di UPT. Laboratorium Kesehatan Daerah Provinsi Sumatera Utara pada bulan Juni 2019, maka diperoleh hasil sebagai berikut :

Sampel sputum dilakukan pengamatan makroskopis dan pemeriksaan mikroskopis sediaan BTA, kemudian sampel disimpan selama 24 jam untuk dibandingkan sifat makroskopis dan pemeriksaan mikroskopis sediaan BTA. 
1. Pengamatan Makroskopis Sputum

Tabel 4.1 Pengamatan Makroskopis Sputum Dari 16 Sampel Sebelum Dan Sesudah Penyimpanan

\begin{tabular}{|l|l|}
\hline Sputum Langsung & $\begin{array}{l}\text { Sputum disimpan 24 jam } \\
\text { suhu 25 } \mathbf{C}\end{array}$ \\
\hline $\begin{array}{l}\text { Sputum Purulen/ } \\
\text { Mukopurulen }\end{array}$ & Sputum encer \\
\hline $\begin{array}{l}\text { Dapat dipisahkan antara } \\
\text { sputum dengan saliva }\end{array}$ & $\begin{array}{l}\text { Tidak dapat dipisahkan } \\
\text { antara sputum dengan } \\
\text { saliva }\end{array}$ \\
\hline Bau khas sputum keruh dan & $\begin{array}{l}\text { Bau lebih tajam } \\
\text { bernampur dengan saliva }\end{array}$ \\
\hline $\begin{array}{l}\text { Warna sputum keruh } \\
\text { saliva bening }\end{array}$ & Sulit dibuat sediaan \\
\hline Mudah dibuat sediaan & \\
\hline
\end{tabular}

Tabel 4.2 Pengamatan Mikroskopis Sediaan Sputum Dari 16 Sampel Sebelum Dan Sesudah Penyimpanan

\begin{tabular}{|l|l|}
\hline Sputum Langsung & $\begin{array}{l}\text { Sputum disimpan 24 jam } \\
\text { suhu } \mathbf{2 5}^{\mathbf{C}} \mathbf{C}\end{array}$ \\
\hline Latar belakang lebih kontras & $\begin{array}{l}\text { Latar belakang ada yang } \\
\text { berjamur }\end{array}$ \\
\hline $\begin{array}{l}\text { Perhitungan jumlah bta } \\
\text { positif lebih mudah }\end{array}$ & $\begin{array}{l}\text { Perhitungan jumlah bta } \\
\text { positif susah dilakukan } \\
\text { karena terdapat jamur yang } \\
\text { mengganggu proses } \\
\text { perhitungan }\end{array}$ \\
\hline $\begin{array}{l}\text { Kesalahan perhitungan } \\
\text { BTA positif lebih rendah, } \\
\text { karena latar belakang dan } \\
\text { BTA terlihat kontras }\end{array}$ & $\begin{array}{l}\text { Kesalahan hitung lebih } \\
\text { tinggi }\end{array}$ \\
\hline
\end{tabular}

\subsection{Pembahasan}

Pemeriksaan dahak mikroskopis efisien, mudah, murah, bersifat spesifik, sensitif dan dapat dilaksanakan di semua unit laboratorium fasilitas pelayanan kesehatan yang memiliki mikroskop dan tenaga mikroskopis TB terlatih.

Sputum yang baik adalah ditampung pada pot yang transparan, volume 3-5 ml, kekentalan mukoid dan warnanya hijau kekuningan (purulent) (Kemenkes RI, 2017).

Hasil dari penelitian secara makroskopis sampel sputum pemeriksaan BTA langsung dan ditunda 24 jam terdapat beberapa perbedaan fisik.

Perbedaan terjadi pada :

1. Kekentalan, sputum awalnya kental (purulent, mukopurulent), setelah disimpan 24 jam pada suhu ruang $\left(25^{\circ} \mathrm{C}\right)$ menjadi encer. Sputum encer bisa terjadi karena suhu ruang yang cendrung hangat $\left(25^{\circ} \mathrm{C}\right)$ dalam waktu 24 jam dapat membuat konsistensi sputum menurun. Suhu hangat dapat menyebabkan pecahnya granula granula pada senyawa sputum, sehingga cairan akan keluar dari granula, dengan demikian tampak lebih encer (Budiharjo, 2016).

Kondisi sputum encer artinya kualitasnya menurun. Sputum encer akan sulit untuk membuat sediaan BTA, karena hasil sediaan akan tipis, kadang sulit rata dan kesimpulannya sediaan tidak baik. Kemenkes RI, 2017 menyatakan bahwa sediaan yang disebut baik adalah harus memenuhi 6 kreteria standar yaitu spesimen purulen/ mukopurulen, pewarnaan baik, bersih, ketebalan baik, ukuran $2 \times 3$ cm dan kerataan $>80 \%$.

2. Bau sputum yang disimpan simpan 24 jam pada suhu ruangan berbau tajam/ menyengat, berbeda dengan bau sputum yang baru yang khas. Perubahan bau sputum disebabkan karena tumbuhnya mikroba pembusuk dan kemungkinan jamur. Sputum adalah sumber nutrisi juga bagi mikroba lain selain Mycobacterium tuberculosis, sehingga sangat dimungkinkan bila dibiarkan pada suhu ruang dapat ditumbuhi oleh mikroba lain seperti jamur dan bakteri pembusuk lain. Bau yang menyengat dapat mengganggu proses pembuatan sediaan, yaitu terhadap petugas yang membuat sediaan BTA.

Adanya jamur dan bakteri/mikroba lain dapat mengganggu pemeriksaan mikroskopis terutama pada pembacaan hasil. Jamur atau mikroba lain dapat menutupi BTA yang terdapat pada sediaan. Hasil pembacaan sediaan dapat menjadi negatif atau positif palsu.

Kualitas sputum sangat menentukan hasil pembacaan sediaan BTA, hasil negatif palsu atau positif palsu dapat menyebabkan salah memberi pengobatan atau tidak diobati yang akhirnya menjadi sumber penularan di masyarakat (Budiharjo, 2016).

Dari 16 sampel sputum langsung dan sputum di simpan selama 24 jam atau lebih pada suhu $25^{\circ} \mathrm{C}$ (suhu kamar) dengan pemeriksaan mikroskopis, didapatkan 7 sampel dengan hasil yang berbeda. Selain menyebabkan perbedaan hasil perhitungan, sediaan yang berasal dari sampel sputum yang disimpan selama 24 jam atau lebih pada suhu $25^{\circ} \mathrm{C}$ membutuhkan waktu yang lebih lama dalam pembuatan sediaan, karena kualitas sputum sudah encer dan menghasilkan sediaan yang tipis yang artinya kualitas contoh uji dan ketebalan tidak baik.

\section{SIMPULAN DAN SARAN}

\subsection{Simpulan}

Berdasarkan dari hasil penelitian yang telah dilakukan terhadap 16 sampel sputum yang diperiksa langsung dan yang dibiarkan 24 jam pada suhu kamar dari sampel yang ada di UPT. Laboratorium Kesehatan Daerah Provinsi Sumatera Utara pada bulan Juni 2019, maka dapat disimpulkan bahwa :

Sampel sputum yang diperiksa langsung secara makroskopis adalah kekentalannya mukoid (tidak encer), warnanya hijau kekuningan (purulen), bau khas sputum.

Sampel sputum yang dibiarkan 24 jam pada suhu kamar adalah kekentalannya mulai berkurang (mencair) sehingga menjadi encer. Warnanya kekuningan kusam, baunya lebih tajam dari sputum langsung periksa dan sebahagian ada cemaran jamur.

Ada pengaruh hasil terhadap penundaan penanganan sampel antara sputum diperiksa langsung dengan yang ditunda 24 jam pada suhu kamar. 


\subsection{Saran}

1. Pemeriksaan sputum BTA sebaiknya dilakukan segera untuk menghindari hasil pemeriksaan mikroskopis positif atau negatif palsu.

2. Apabila sputum akan diperiksa lebih dari 24 jam, agar hasilnya akurat dan tidak semu, sebaiknya disimpan pada suhu $4^{\circ} \mathrm{C}-8^{\circ} \mathrm{C}$ atau dengan menggunakan bahan pengawet.

3. Untuk peneliti selanjutnya, sebaiknya menggunakan sampel penelitian yang lebih banyak.

\section{DAFTAR PUSTAKA}

Dinas Kesehatan Provinsi Sumatera Utara, 2017. Profil Kesehatan Provinsi Sumatera Utara Tahun 2016.

Kemenkes RI, 2011. Modul Pelatihan Pemeriksaan Mikroskopis TB. Jakarta.

Kemenkes RI, 2012. Petunjuk Teknis Pemeriksaan Biakan, Identifikasi dan Uji Kepekaan Mycobacterium Tuberculosis pada Media Padat. Jakarta.

Kemenkes RI, 2012. Standar Operasional Prosedur Pemeriksaan Mikroskopis Tuberkulosis. Jakarta

Kemenkes RI, 2012. Modul Pelatihan Pemeriksaan Dahak Mikroskopis TB. Jakarta.

Kemenkes RI, 2013. Pedoman Jejaring Dan Pemantapan Mutu Pemeriksaan Mikroskopis Tuberkulosis. Jakarta.
Kemenkes RI, 2013. Petunjuk Teknis Pembuatan Sediaan Rujukan Mikroskopis Tuberkulosis Untuk Uji Profisiensi. Jakarta.

Kemenkes RI, 2014. Pedoman Nasional Penanggulangan TB. Jakarta.

Kemenkes RI, 2015. Standar Pelayanan Laboratorium Tuberkulosis, Jakata.

Kemenkes RI, 2015. Pedoman Jejaring Dan Pemantapan Mutu Laboratorium Tuberkulosis. Jakarta.

Kemenkes RI 2017. Kebijakan Penanggulangan TB.

Kemenkes RI 2017. Modul Pelatihan Laboratorium Tuberkulosis Bagi Petugas di Fasyankes.

Girsang Merryani, 2012. Mycobacterium Penyebab Penyakit Tuberculosis Serta Mengenal Sifat- sifat Pertumbuhannya di Laboratorium. Jakarta.

Teguh Budiharjo, Kundjoro Adi Purjanto, 2016. Pengaruh Penanganan Sputum Terhadap Kualitas Sputum Penderita TBC Secara Mikroskopis Bakteri Tahan Asam. Jurnal Riset Kesehatan. Semarang

WHO, 2016. Global Tuberculosis Report. 2016 (WHO/HTM/TB/2016.13). www.who.int/tb/publications/global/report/en/ . Date last accessed: March 27, 2019. 